\title{
Xunzi and Han Fei on Human Nature
}

\author{
Alejandro Bárcenas
}

\begin{abstract}
It is commonly accepted that Han Fei studied under Xunzi sometime during the late third century BCE. However, there is surprisingly little dedicated to the in-depth study of the relationship between Xunzi's ideas and one of his best-known followers. In this essay I argue that Han Fei's notion of xing, commonly translated as human nature, was not only influenced by Xunzi but also that it is an important feature of his political philosophy.
\end{abstract}

"Aus so krummem Holze, als woraus der Mensch gemacht ist, kann nichts ganz Gerades gezimmert werden." -Immanuel Kant, Idee zu einer allgemeinen Geschichte in weltbürgerlicher Absicht.

\begin{abstract}
$\mathrm{A}^{\mathrm{T}}$
T FIRST SIGHT, IT DOES not seem far-fetched to suggest that a thorough study of Han Fei's notion of xing (性) — commonly translated as human nature-should include an analysis of the role played by his teacher Xunzi. However, suggesting the existence of such influence has proven to be a quite controversial topic. For the most part recent interpreters of the history of Chinese philosophy tend to briefly mention the existence of some sort of philosophical relationship between Xunzi and Han Fei. ${ }^{1}$ What scholars generally acknowledge is that a master-student relationship existed between the two, which typically indicates some kind of influence (or rejection) of one by the other. However, there is surprisingly little dedicated to the in-depth study of the relationship between Xunzi's ideas and one of his bestknown followers. This absence of detailed analysis is even more puzzling when it is contrasted with the profuse amount of research during recent years, dedicated to comparing Xunzi with Mencius, his most famous counterpart. ${ }^{2}$ In the following
\end{abstract}

${ }^{1}$ See, Geng Wu, Die Staatslehre des Han Fei: ein Beitrag zur chinesischen Idee der Staatsräson (Vienna: Springer, 1978) p. 41; A. C. Graham, Disputers of the Tao: Philosophical Argumentation in Ancient China (La Salle: Open Court, 1989), p. 268; Chad Hansen, A Daoist Theory of Chinese Thought: A Philosophical Interpretation (New York: Oxford University Press, 1992), p. 357; John Knoblock, introduction to Xunzi: A Translation and Study of the Complete Works (Stanford: Stanford University Press, 1988), pp. 36-37; Yuk Wong王显, "Han Feizi (Han Fei Tzu)" in Encyclopedia of Chinese Philosophy, ed. Antonio S. Cua (New York and London: Routledge, 2003), p. 285; JeeLoo Liu 劉紀璐, An Introduction to Chinese Philosophy: From Ancient Philosophy to Chinese Buddhism (London: Blackwell, 2006), p. 182; Karyn L. Lai, An Introduction to Chinese Philosophy (New York: Cambridge University Press, 2008), p. 186; and Yuri Pines, Envisioning Eternal Empire: Chinese Political Thought of the Warring States Era (Honolulu: University of Hawai'i Press, 2009), p. 106.

${ }^{2}$ See for instance, David E. Soles, "The Nature and Grounds of Xunzi's Disagreement with Mencius," Asian Philosophy 9 (1999): 123-33; D. C. Lau 劉殿爵, “Theories of Human Nature in Mencius and Xunzi” in 
pages I will argue that there are some important reasons for the considerable lack of interest or even intentional silence regarding this subject and that the lack of interest is based, in no small measure, on the way Han Fei was read by some of the most influential scholars in the field. I will also suggest that Han Fei's notion of xing was not only influenced by Xunzi but also that it is an important feature of his political philosophy.

\section{XUNZI'S INFLUENCE}

The historical fact of the master-student relation between Xunzi and Han Fei is based on the accounts of the first century BCE historian Sima Qian (司馬遷). Sima Qian indicates in his biography of Han Fei that he studied under Xunzi, just like Li Si (李斯), who was an advisor to Qin Shi Huang (秦始皇), the first unifier of China. ${ }^{3}$ This crucial passage was written by Sima Qian in book LXIII of his Shiji (史記), commonly translated as Records of the Grand Historian, during the rule of the Emperor Wu (武) of the Han (漢) dynasty, some one hundred and fifty years after Han Fei's death. The passage in question reads, "Han Fei had a speech impediment and was not a proficient orator but was a skilful writer and, in these matters, he and Li Si were followers of Xunzi."4

Sima Qian's writings are the closest records that exist from that time with regard to Han Fei's life. It is commonly accepted that Han Fei and Li Si studied under Xunzi during the time he was a magistrate in Lanling (蘭陵), an ancient city located near the birthplace of Han Fei. ${ }^{5}$ In Lanling, Xunzi was appointed the magistrate by Prince Chunshen Jun (春申君) in 255 BCE when he was about sixty-one years old and remained in the area for the rest of his life. ${ }^{6}$ Hence, as a mature philosopher, it is quite possible that Xunzi created a lasting impression in his young pupils.

But for some scholars, such as Shigeki Kaizuka, there seems to be certain textual elements that might make this key story doubtful ${ }^{7}$ and while others such as Lundahl

Virtue, Nature, and Moral Agency in the Xunzi, ed. Philip J. Ivanhoe (Indianapolis: Hackett, 2000); Kimchong Chong 莊錦章, “Xunzi’s Systematic Critique of Mencius," Philosophy East and West 53 (2003): 215-33; Maurizio Scarpari, “The Debate on Human Nature in Early Confucian Literature," Philosophy East and West 53 (2003): 323-39; Jiyuan Yu, "Human Nature and Virtue in Mencius and Xunzi: An Aristotelian Interpretation," Dao: A Journal of Comparative Philosophy 5 (2006): 11-30; Kim-chong Chong, "Xunzi and the Essentialist Mode of Thinking on Human Nature," Journal of Chinese Philosophy 35 (2008): 63-78.

${ }^{3}$ See Philip J. Ivanhoe and Bryan W. Van Norden, Readings in Classical Chinese Philosophy (Indianapolis: Hackett, 2006), p. 311; Fun Yu-lan [Feng You-lan] 馮友蘭, A History of Chinese Philosophy: The Period of the Philosophers, from the Beginnings to Circa 100 B. C., trans. Derk Bodde (Princeton: Princeton University Press, 1952), p. 320.

4“非為人口吃, 不能道說，而善著書，與李斯俱事荀卿.” Sima Qian 司馬遷, Shiji 史記 (Beijing: Zhonghua shuju, 1959), chapter 63.

${ }^{5}$ Bertil Lundahl, Han Feizi: The Man and His Work (Stockholm: Institute of Oriental Languages, 1992), p. 47. See also, Hansen, A Daoist Theory of Chinese Thought, p. 344.

${ }^{6}$ Masayuki Sato 佐藤將之, The Confucian Quest for Order: The Origin and Formation of the Political Thought of Xun Zi (Leiden: Brill, 2003), p. 55.

${ }^{7}$ Kaizuka affirms that unlike Li Si, Han Fei is never mentioned as a student of Xunzi in any other record of the time. See Shigeki Kaizuka 貝塚 茂樹, Kanpi 韓非 (Tokyo: Kodansha, 1982), pp. 47-49. Lundahl, following the arguments put forward by Kaizuka, points out that in addition to a lack of other contemporary references, "the Han Feizi has very little to say about Xunzi, if anything at all" (Lundahl, Han Feizi, p. 47), 
provide convincing arguments against this rather undue line of thought, their own writing still continues to transmit and emphasize the traditional dismissive sentiment expressed by a large majority of the Sinological studies dedicated to Han Fei. For instance, Lundahl himself concludes that, "the silence of Han Fei regarding his master remains a problem to be explained." But, given that recent studies have began to make some attempts to explore the relationship between the master and his student, one wonders if such silence is just a fabrication of certain interpreters as a result of their unwillingness to link Xunzi to Han Fei.

It appears that for some of the mid-twentieth century scholars of Chinese philosophy Han Fei's ideas seemed to be too toxic to be worth exploring. The fear may exist that associating Han Fei's work with Xunzi could endanger the already weak reputation of Xunzi as a Confucian, in particular after Zhu Xi (朱喜) did not include Xunzi's text in the Confucian canon, known as the Four Books (sishu四書), ${ }^{9}$ during the Song (宋) Dynasty.

Burton Watson, for instance, is a key representative-and perhaps in its most extreme case - of the fear to link Han Fei to Xunzi. In the introduction to his translation of Xunzi's writings, he comments that,

[Xunzi] undoubtedly had many disciples, and it is unfortunate for his reputation as a Confucian that two of the most famous of them should have been Han Feizi, who became the leading exponent of the Legalist $\mathrm{School}^{10}$ and $\mathrm{Li} \mathrm{Si}$, the statesman who assisted the First Emperor of the Qin in the unification of the empire, both men whose names are inseparably linked with the ridicule and persecution of Confucianism. ${ }^{11}$

and the few passages that could have had an explicit reference to his teacher seem to be rather doubtful. Kaizuka has even gone so far as to conclude that Han Fei could not have been a student of Xunzi (Kaizuka, Kanpi, pp. 63-69) based on the apparent mistakes made by Han Fei of placing Chunshen Jun (春申君), the famous protector of Xunzi, during the Spring and Autum period some two hundred years earlier than his real lifetime and also failing to mention Xunzi in a passage that was a direct reference to a letter written by Xunzi to Chunshen Jun. However, as Lundahl points out, Kaizuka's premature conclusion relies merely on two passages and therefore, it seems particularly impulsive because it assumes firstly that no word was ever changed during the long transmission of the text and, secondly, that additional records from the time were never not destroyed or lost.

${ }^{8}$ Lundahl, Han Feizi, p. 49.

${ }^{9}$ The four books are the daxue (大學), zhong yong (中庸), lunyu or Analects (論語) and the book of Mencius (孟子).

${ }^{10}$ Even though the Han Dynasty historian, Sima Tan (司馬談), considered Legalist philosophy a school or fa jia (法 家), there are significant philosophical differences between its members and it would be erroneous to state that there is a unifying ideology shared by all within the so-called "school." In this essay I will focus solely on explaining Han Fei's Legalist notions, which are significantly different from those of Shen Buhai (申不害) or Shang Yang (商鞅). Han Fei himself dedicated an entire chapter to refute some of the precepts defended by both philosophers (chapter XLIII). I will simply limit myself to pointing out that such differences exist since explaining them in detail is beyond the scope of the present essay. For more on the subject see, Wm. Theodore de Bary and Irene Bloom, eds., Sources of Chinese Tradition vol. 1 (New York: Columbia University Press, 1999), p. 279; Kidder Smith, "Sima Tan and the Invention of Daoism, 'Legalism,' et cetera,' The Journal of Asian Studies 62 (2003): 129-56; Paul R. Goldin, "Persistent Misconceptions about Chinese 'Legalism,"' Journal of Chinese Philosophy 38 (2011): 88-104; and Soon-ja Yang, "Shen Dao's Own Voice in the Shenzi Fragments," Dao: A Journal of Comparative Philosophy 10 (2011): 187-207.

${ }^{11}$ Burton Watson, introduction to Xunzi: Basic Writings (New York: Columbia University Press, 2003), pp. 2-3. For more on the early reception of the Han Feizi see Michael Andrew Hall Reeve, "Demostrating 
As Watson explained, it was unfortunate for the legacy of Han Fei's thought that he was such a harsh critic of the Confucian School, which dominated the social and political structure of China for most of its history. The result has been that even now, many centuries after his death, his ideas are shrouded by a number of preconceptions that prevent scholars from examining Han Fei's thought on its own terms. ${ }^{12}$

While Lundahl, Kaizuka and Watson are all representative of the dominant hermeneutical tendency of Sinology, some of the most prominent philosophical studies are no different in that they suffer from a very similar dismissive spirit and rarely attempt to go further than simply mentioning that Han Fei studied under Xunzi based on the aforementioned passage by Sima Qian. On most occasions, however, many prominent authors simply have preferred avoiding the issue altogether in their surveys of Chinese philosophy. ${ }^{13}$

Among the major authors who have explored the history of classical Chinese philosophy in the twentieth century, Feng You-lan seems to be the only one-and perhaps the first - who considered in his History of Chinese Philosophy the relationship between Xunzi and Han Fei worthy of some attention. Unfortunately his thoughts regarding this matter were limited to saying, "most Legalists believe that man's nature is evil, and Han Fei Tzu [Han Feizi], as the disciple of Hsün Tzu [Xunzi], is especially clear in this point." ${ }^{14}$ Feng neither elaborated on the significance of his assessment nor supported his arguments with passages which directly address the notion of the natural tendencies of people $(x i n g) .{ }^{15}$ Nevertheless, Feng

the World: Mind and Society in the Shuo Lin chapters of the Han Feizi" (PhD diss., Princeton University, 2003), chap. 1.

${ }^{12}$ Flanagan and Hu suggest the existence of a hermeneutical bias against Han Fei that "nudges philosophers and other interpreters of theories of human nature to give extra credit points to flattering theories." Owen Flanagan and Jing Hu, "Han Fei Zi’s Philosophical Psychology: Human Nature, Scarcity and the Neo-Darwinian Consensus," Journal of Chinese Philosophy 38 (2011): 295.

${ }^{13}$ The following list of works does not pretend to be a comprehensive examination of the secondary literature. Its intention is to point out the pervasive lack of interest in studying the relationship between Xunzi and Han Fei in some of the most widely used surveys of Chinese philosophy and critical editions of the Han Feizi. In addition, I have focused primarily on works in Western languages. For the surveys I have indicated the chapters or pages dedicated to Han Fei. See, D. T. Suzuki 鈴木大拙, A Brief History of Early Chinese Philosophy (London: Probsthain, 1914), chap. 2; Giuseppe Tucci, Storia della filosofia cinese antica (Bologna: Zanichelli, 1922), chap. 7; Alfred Forke, Geschichte der alten chinesischen Philosophie (Hamburg: L. Friederichsen, 1927), chap. 7; Marcel Granet, La pensee chinoise (Paris: La Renaissance du Livre, 1934), book IV, part I; Arthur Waley, Three Ways of Thought in Ancient China (London: G. Allen \& Unwin, 1939), chap. 3; Chen Qiyou 陳奇猷, Han Feizi ji shi 韓非子集釋 (Beijing: Zhonghua shu ju, 1958); Léon Vandermeersch, La formation du légisme: recherche sur la constitution d'une philosophie politique caractéristique de la Chine ancienne (Paris: École Française d'Extrême-Orient, 1965), chap. 9; Joseph Needham, Science and Civilisation in China (Cambridge: Cambridge University Press, 1969), vol. 2, chap. 12; Benjamin I. Schwartz, The World of Thought in Ancient China (Cambridge and London: Harvard University Press, 1985), chap. 8; Wilmar Mögling, Die Kunst der Staatsführung: die Schriften des Meisters Han Fei (Leipzig: Gustav Kiepenheuer, 1994); Anne Cheng, Histoire de la pensée chinoise (Paris: Seuil, 1997), chap. 9; Yao Ning 姚寧 and Gabriel García Noblejas, Han Feizi: El Arte de la Política (Madrid: Tecnos, 1998); Jean Levi, Han-Fei-tse, ou, le Tao du Prince: la stratégie de la domination absolue (Paris: Éditions du Seuil, 1999); Bo Mou, ed., History of Chinese Philosophy (London and New York: Routledge, 2009).

${ }^{14} \mathrm{Feng}$, A History of Chinese Philosophy, p. 327.

${ }^{15}$ Xing will be translated as "natural tendencies" instead of the more common "human nature" in order to avoid "suggesting a classical teleological conception, associated with the notion of a universal human 
made a significant preliminary attempt to approach the issue and he acknowledged that the existence of the master-student relationship played an important role in Han Fei's philosophy.

On the other end of the philosophical spectrum is Wing-tsit Chan, who in his widely read Source Book in Chinese Philosophy, not only took the side of but also continued to influence those who would prefer to avoid the issue altogether. In the only section where Chan commented on the relationship between Xunzi and Han Fei, he did so only to disagree entirely with Feng. Chan seemed to think that even suggesting a relationship between the two is problematic. He wrote, "it is misleading, at least, to say, as Fung [Feng] does, that Han Fei Tzu [Han Feizi] based his doctrines on the teachings of Hsün Tzu [Xunzi]." "16 Yet in spite of this, Chan surprisingly could not avoid agreeing with Feng to a certain extent. Chan concluded, as Feng did before him, that "the theory of the originally evil nature of man is a basic assumption of the Legalist." 17

Feng and Chan's works have become so influential that they have provided the core beliefs and guidelines for most attempts to study the relationship between Xunzi and Han Fei. In this sense, their contributions have provided an indispensable hermeneutical background for those of us who follow in their footsteps. But a thorough study of the philosophical period of Han Fei's life needs to comprehend these ideas by taking into careful consideration how they were originally conceived and how they were meant to be read. ${ }^{18}$ This is to say, they are to be seen as a direct result of the intellectual and historical environment of the Warring States period. Once again, this is the reason why one cannot and must not neglect the intellectual influence played by Xunzi during this time-one of the most important minds of the period-because his view of humanity is one that serves as background for, not only his own revision of Confucian philosophy, but also to others such as $\mathrm{Li} \mathrm{Si}$ and Han Fei. The following pages will examine this possible influence in order to gain a broader understanding of Han Fei's Legalism and to be able to recognize his unique philosophical contribution to the period.

essence, invariant in all times and places." Michael Sandel, Liberalism and the Limits of Justice (Cambridge: Cambridge University Press, 1982), p. 50. The latter translation erroneously ascribes to classical China, what Roger T. Ames has called, "an essentialist understanding of human nature." Roger T. Ames, "Mencius and a Process Notion of Human Nature" in Mencius: Contexts and Interpretations, ed. Alan K. L. Chan (Honolulu: University of Hawai'i Press, 2002), p. 72. For more on the subject see, Dan Robins, "The Warring States Concept of Xing," Dao: A Journal of Comparative Philosophy 10 (2011): 31-51.

${ }^{16}$ Wing-tsit Chan 陈荣捷, A Source Book in Chinese Philosophy (Pricenton: Princeton University Press, 1963), p. 254. Chan's conclusion, however, was reached without providing supporting arguments or textual evidence.

${ }^{17}$ Chan, A Source Book in Chinese Philosophy, p. 254. Landers, following Chan's line of thought, comments, "Han Fei was less concerned with man's basic nature and more concerned with political and social affairs [than Xunzi] and consequently did not specifically express his ideas on man's basic nature. Yet it is evident that Han Fei was indeed influenced by Xunzi's theory that man was evil by nature." James R. Landers, "The Political Thought of Han Fei” (PhD diss., Indiana University, 1972), pp. 97-98.

${ }^{18}$ In this regard, I am following Skinner's suggestion that the appropriate method to adopt in studying the history of ideas should be concerned with grasping "what [the texts] were intended to mean and how that meaning was intended to be taken.” Quentin Skinner, Visions of Politics: Regarding Method (Cambridge: Cambridge University Press, 2002), p. 86. 


\section{THE NATURE OF HUMANITY}

Despite some noticeable differences between their philosophical systems, ${ }^{19}$ a group of scholars, particularly during the last two decades, have begun to mention several diverse ways in which Xunzi's thought might have influenced Han Fei's political philosophy. As a better picture of the relationship between the two philosophers starts to take form, it is possible to sustain the position that Xunzi's influence might not have been superficial or limited to a few scattered or insignificant ideas. To this effect, Yuri Pines suggests in his book Envisioning Eternal Empire: Chinese Political Thought of the Warring States Era that, "Xunzi and Han Fei appear much closer to each other than first impressions led us to believe."20

Among those scholars contributing to the new picture of the relationship between Xunzi and Han Fei, Pines deems Han Fei to be "Xunzi's disciple and intellectual rival, [who] matched the sophistication of his master" 21 and influenced him on an attempt to give the ruler "a symbolic presence." 22 Chad Hansen has suggested that, "Xunzi influences the deep structure of Han Feizi's philosophical thought"23 and Paul Goldin has attributed "the assertion that the Way is the "skein of right and wrong" to Xunzi's influence over Han Fei. ${ }^{24}$ In addition to those discerning suggestions - which unfortunately remain largely undeveloped by their respective authors-I would like to propose, following the early insight by Feng and other scholars ${ }^{25}$ inspired by him who have made preliminary attempts to link Han Fei to Xunzi, that perhaps Xunzi's most important legacy for Han Fei was the content of his radically new perception of the natural tendencies of humans.

By taking into account that Han Fei discusses the issue of the natural tendencies of humans (xing 性) on more occasions than the three most prominent members of

${ }^{19}$ For a detailed explanation of their differences, see Chung-ying Cheng 成中英, New Dimensions of Confucian and Neo-Confucian Philosophy (Albany: State University of New York Press, 1991), pp. 327-29; and Roger T. Ames, The Art of Rulership: A Study of Ancient Chinese Political Thought (Albany: State University of New York Press, 1994), chap. 4.

${ }^{20}$ Pines, Envisioning Eternal Empire, p. 106.

${ }^{21}$ Ibid.

${ }^{22}$ Ibid., pp. 102-07.

${ }^{23}$ Hansen, A Daoist Theory of Chinese Thought, p. 357. In 1959, W. K. Liao made the remark that, "the superior man, or plainly, gentleman [junzi 君子] was taken as the model man, which was, no doubt, due to the Confucian influences Han Fei Tzu had received from Hsun Tzu [Xunzi] under whom he had spent the formative period of his thought." The Complete Works of Han Fei Tzu: A Classic of Political Science, trans. W. K. Liao 廖文奎 (London: A. Probsthain, 1959), p. 28.

${ }^{24}$ See, Paul R. Goldin, “Han Fei’s Doctrine of Self-interest,” Asian Philosophy 11 (2001): 158.

${ }^{25}$ Chung-ying Cheng, for instance, writes, "Xunzi holds the view that human nature is bad-a view which both Han Fei and Li Si accepted as a basis for their Legalistic theory of government." Cheng, New Dimensions of Confucian and Neo-Confucian Philosophy (Albany: State University of New York Press, 1991), p. 326. See also, Wolfgang Bauer, Geschichte der chinesischen Philosophie: Konfuzianismus, Daoismus, Buddhismus, ed. Hans van Ess (Munich: Beck, 2006), 114; Liu, An Introduction to Chinese Philosophy, pp. 184-85; Lai, An Introduction to Chinese Philosophy, p. 186; Zhao Dunhua 赵敦华, “Axiological Rules and Chinese Political Philosophy," Journal of Chinese Philosophy 34 (2007): 170; Peter R. Moody, "Rational Choice Analysis in Classical Chinese Political Thought: The Han Feizi." Polity 40 (2008): 106; and Albert Galvany, "Instrumentalización de las pasiones, regulación social y trascendencia del poder en el Hanfeizi 韓非子,” Digithum 10 (2008), http://www.uoc.edu/digithum/10/dt/esp/galvany.pdf. 
the so-called Legalist school combined — Guanzi, Shen Buhai and Shang Yang, ${ }^{26}$ —it is quite possible to maintain that it is a unique feature of his political philosophy. Furthermore, it is reasonably possible to say that it became a distinctive feature of Han Fei's philosophy due to the inspiration of his teacher Xunzi, who developed the notion of xing in a more detailed and consistent way than any other Confucian before him, thus, showing what A. C. Graham called a "progress of argumentation in the Confucian school." ${ }^{27}$

There are two chapters in Xunzi's writing that seem to have played the most crucial role in this regard: chapter 9, entitled "Advice for Kings" (王制 wangzhi) and, perhaps the most commented upon section of the Xunzi, chapter 23 entitled "Natural Tendencies are Undeveloped" (性惡 xing $e$ ), traditionally translated as "Human Nature is Evil.". 28

Xunzi must have considered that his conception of xing was a key feature of his philosophy and perhaps even the most important concept in his refutation of Mencius. The main focus of his arguments was to establish the fundamental ground that could help us understand how human beings were capable of overcoming their original crude shortcomings and begin to act according to the standards of society in a voluntary and conscious way.

As previously mentioned, Feng pointed out that Han Fei, following Xunzi, also thought that xing had intrinsic undeveloped traits. Feng based his assessment on several chapters in which Han Fei described what seemed to be negative and therefore harmful characteristics of humanity. ${ }^{29}$ He then concluded, "all men, Han Fei Tzu [Han Feizi] insists, act from motives of selfishness and self-profit, and so 'show calculating minds in their attitude' toward one another." ${ }^{30}$ But in those passages used by Feng to support his conclusion, Han Fei was not, strictly speaking, addressing the notion of natural tendencies nor was he using the term xing at all. Instead, what Han Fei wrote in those passages was a description of how undeveloped people behave under unfavorable social conditions while at the same time acting in accordance to Confucian ideals. So, as a result, Feng's description of the entire picture of Han Fei's notion of the natural tendencies of humans remained incomplete.

Still, a growing number of scholars, inspired in no small degree by Feng, affirm that Han Fei inherited from Xunzi the conception that at least part of the content

\footnotetext{
${ }^{26}$ See, Shang Yang, 新譯商君書 Xin Yi Shang Jun Shu, ed. Yuanchen Bei 貝遠辰 (Taibei: San min shu ju, 1996); Shen Buhai, 新譯管子讀本二十四卷 Xin Yi Guan Zi Du Ben Er Shi Si Juan, ed. Xiaochun Tang 湯孝純 (Taibei: San min shu ju, 2006). For English translations of their works see, J. J. L. Duyvendak, trans., The Book of Lord Shang: A Classic of the Chinese School of Law (Chicago: University of Chicago Press, 1963); W. Allyn Rickett, trans., Guanzi: Political, Economic, and Philosophical Essays from Early China: A Study and Translation (Princeton: Princeton University Press, 1985-1998); and Herrlee G. Creel, trans., Shen Pu-hai: A Chinese Political Philosopher of the Fourth Century B.C. (Chicago: The University of Chicago Press, 1974).

${ }^{27}$ Graham, Disputers of the Tao, p. 244.

${ }^{28} E$ 惡 will be translated as "undeveloped" or "raw" instead of the traditional "evil." Taking into account the context in which $e$ is used as a philosophical term in both the Xunzi and the Han Feizi, it is clear that $e$ refers to the characteristics of human natural tendencies before they have been influenced by education and society and not as a notion opposite to the "good."

${ }^{29}$ Han Feizi, chapters XXXII, XLVI and L.

${ }^{30}$ Feng, A History of Chinese Philosophy, pp. 327-30.
} 
of humanity has an "evil," "negative," or-more accurately—an undeveloped side. Han Fei referred to this undeveloped side of humanity in several chapters in his writings. For instance, in chapter LIV Han Fei expressed his concern that when people remained undeveloped, they have no desire to be productive members of society. He described his impression in the following way, "it is among people's natural tendencies to dislike physical labor and enjoy leisure." ${ }^{31}$ Furthermore, as undeveloped beings, people do not possess the proper capability to contribute to the improvement of society. Han Fei concluded in chapter XL that, "as for the inclinations of the natural tendencies, worthies are few and worthless persons many." ${ }^{\prime 2}$ The catastrophic consequence of remaining in such an untidy social condition was that "it is amongst people's natural tendencies to delight in chaos and detach themselves from laws." 33

But neither Feng nor those who follow his line of thought noticed an important nuance in Han Fei's writings regarding his entire argument of the natural tendencies of humans. As the previous passages suggest, Han Fei does agree with Xunzi that natural tendencies have undeveloped traits. Yet he also argued that, in general, people seemed to have other inclinations present within their natural tendencies, which lets them know what is beneficial for them as a whole, as opposed to self-centered, private interests ( $s i$ 私). JeeLoo Liu, for example, seems to be one of the very few scholars to capture the whole complexity of Han Fei's conception of the natural tendencies of people when she writes, "Han Fezi seems to think that people generally share such moral attributes such as kindness and generosity (or their opposites such as callousness and parsimony), but they exemplify different traits because of their various external circumstances." ${ }^{34}$

Apart from the features mentioned by Liu, perhaps Han Fei valued above all the constancy demonstrated by people to properly distinguish bad rulers from good ones. In one instance, Han Fei elaborated on the value of such constancy through a fictional conversation between Confucius and his disciples. In the story, Confucius comments on the actions perpetrated by Duke Bai (白公) in relation to the fate of a government official of the state of Chu (楚) named Zixi (子西) (originally recorded in book XII of the Zuo Commentary of the Spring and Autumn Annals [Chunqiu Zuozhuan 春秋左傳]). ${ }^{35}$ In the Zuozhuan, it is told that Zixi helped promote and gave the command of an entire army to Duke Bai in spite of his reputation of being

31“夫尼之性，惡勞而樂佚.” Han Feizi, chapter LIV. All references to the Han Feizi are from Xinyi Han Feizi 新譯韓非子, ed. Fu Wuguang 傅武光 and Lai Yanyuan 賴炎元 (Taibei: Sanmin Shuju, 2003). Unless otherwise noted, all translations are my own. However, I have consulted Liao, The Complete Works of Han Fei Tzu; Mögling, Die Kunst der Staatsführung; Ning and García Noblejas, Han Feizi; Lévi, Han-Fei-tse; and Han Feizi: Basic Writings, trans. Burton Watson (New York: Columbia University Press, 2003). Citations include the name of the work followed by the chapter.

32“人之情性，賢者寡而不肖者 眾.” Han Feizi, chapter XL.

33“夫民之性，喜其亂而不親 其法.” Han Feizi, chapter LIV. “As for fa," Graham writes “it is the old word for a model or standard for imitation." Graham, Disputers of the Tao, p. 270.

${ }^{34} \mathrm{Liu}$, An Introduction to Chinese Philosophy, p. 184.

${ }^{35}$ See, Chunqiu Zuozhuan 春秋左傳, Book XII 哀公, Sixteenth Year, in James Legge, The Chinese Classics, volume V: The Ch'un ts'ew, with the Tso chuen (Hong Kong: Hong Kong University Press, 1960), pp. 843-45. 
deceitful and insubordinate. Zixi was ultimately trying to use Duke Bai's skills as a warrior for his own selfish ends so he hid the Duke's true personality from the king and falsely portrayed him as someone who was bold and trustworthy. Five years later, in $474 \mathrm{BCE}$, out of anger at not being able to take revenge against his father's assassin (with whom Zixi had signed a peace treaty) and emboldened by his newfound power, Duke Bai led a rebellion against his own state of Chu and Zixi ended up dying at the hands of the Duke during an ambush.

For Han Fei, Zixi's case served as a very clear example of somebody who did not cultivate restraint in his ambition and hence, someone who could not achieve lasting political success. But most importantly, Zixi was judged by the constant (heng恆) and steady criteria of the natural tendencies of people who were capable of distinguishing dishonest from honest individuals in spite of their appearances and, as a result, Zixi has since then been relegated to a shameful place in history. ${ }^{36}$

The notion of constancy (heng恆), which is mentioned in this passage with regard to xing, was a notion praised by Confucius himself throughout the Analects. ${ }^{37}$ But whereas Confucius hoped to find constancy only among those who have developed their persona through education and experience, such as sages (shengren聖人) or exemplary persons (junzi 尹尹尹 $\}$ ), Han Fei explained that history has proven that constancy is already a feature belonging to natural human tendencies. People, regardless of the period of time when they live, seem to possess a constancy in their nature that makes them capable of understanding what is beneficial to them and what leads to chaos and destruction.

This positive feature of the natural tendencies of people is the reason why Han Fei believed that it needed to be protected to achieve a stable society. Han Fei asserted that rulers become weak if they are unable to understand the differences between what is to be preferred ( $s h i$ 是) and what is not ( $f e i$ 非). By not separating these two choices, they set appearances in the place of natural tendencies and, consequently, made decisions based on wrong premises. Han Fei explained that this was the very reason why Jie (桀) the last ruler of the Xia (夏) dynasty, who became notorious in Chinese history for his cruelty, lost his hitherto powerful empire to Tang (湯), the first king of the Shang (商) dynasty. Jie behaved cruelly towards those who were born with defects by declaring them as unfit to live. The king surmised that a flaw in their physical appearance was equal to a flaw in their natural tendencies. Han Fei was concerned that instead of taking into account what people are in themselves,

\footnotetext{
${ }^{36}$ "Confucius once asked his disciples 'who can tell me how Zixi gained his reputation?' 'Zixi himself should answer,' replied Zigong and nobody would be able to doubt him. Confucius said, 'be broadminded, do not have a desire for profit. Be measured because people's natural tendencies have constancy. They consider crookedness crooked and straightness straight. [Thus], Zixi could not evade a disastrous end.' During the rebellion of the Duke Bai, Zixi was killed.' (子謂弟子曰: 『孰能導子西之釣名也 ? 』子貢曰: 『賜也能。』乃導之, 不復疑也。孔子曰: 『寬哉, 不被於利; 絜哉, 民性有恆。曲為曲, 直為直。孔子曰子西不免。 』白公之難, 子西死 焉).” Han Feizi, chapter XXIII. For Zigong in the Analects, see 1.15, 3.17, 6.8, 7.15, 17.19. All references to the Analects are from Xinyi Sishu Duben 新譯四書讀本, ed. Bingying Xie 謝冰瑩, et al. (Taibei: Sanmin Shuju, 2003).

${ }^{37}$ See, Analects, 7.26, 13.22 .
} 
Jie only focused on their physical appearance, while concurrently rewarding those who appeared to be skillful but were in reality hypocrites, and therefore making his state weak. ${ }^{38}$

In his critique of King Jie, Han Fei assigned an important role to the respect and value of natural tendencies in order to construct a stable, prosperous and long-lasting government. To respect and appreciate the natural tendencies of people meant that the highest source of order, that is to say, the patterns (li理) of the heavens were being followed, as Han Fei explained, in the following passage, "the ancients never went against the patterns of the heavens, nor damaged the inclinations of the natural tendencies." 39

Even though for Han Fei humans are transformed according to the culture of their historical period, there is certain constancy, inclinations and value to the natural tendencies of a group of people that need to be taken into account to form a longlasting government that is in harmony with tian. Consequently, rulers should not hope to perpetuate their power by thinking they are capable of forcefully changing what defines the inhabitants of a historical period. That is the reason why, as Han Fei explained, the ancients never asked mythical figures to use their great skill to break or interrupt social order at their will, nor asked them to use their power to hurt the natural tendencies of the people..$^{40}$

\section{INCLINATIONS AND DESIRES}

Finally, there is another element embraced by Han Fei in his perception of society that he considered vital for the achievement of peace and order, which might have been inspired by Xunzi. Xunzi argued that, in general terms, the natural tendencies inherent to any person are raw and undeveloped ${ }^{41}$ and that they are particularly likely to fall under the seductive rule of desires,

\footnotetext{
38" Jie was the son of the heavens, but did not know what is to be preferred from what is not and rewarded those without skills. He took slanderers and flatterers into service and consciously gave them wealth; he executed those who did not commit crimes and ordered that the backs of humpbacks be excised because of their natural tendencies given by the heavens. Hence, he consciously place those actions as what is to be preferred and the natural tendencies of the heavens as something that should not be preferred, and a small state could defeat his large one (桀天子也, 而無是非, 賞於無功; 使堍課, 以詐偽為貴; 誅於無罪 使傴以天性剖背；以詐偽為是，天性為非，小得 勝 大).”Han Feizi, chapter XXV.

39““古］不逆天 理，不傷 情 性. Han Feizi, chapter XXIX.

40"Even if Craftsman Stone, in wanting to rectify Mount Tai [Mount Tai is a sacred daoist mountain and a prevalent symbol of political stability in ancient China] were to use a lifetime of a thousand years to apply his scythe, to measure it with his compasses and squares, and to right it with his ink string, and even if Ben and $\mathrm{Yu}$, in wanting to bring order to the people, gave the task at hand all of their strength and expended their entire lives in their efforts, Mount Tai would not be rectified, and the people would not be properly ordered. Hence the saying: "The ancient rulers of all under the heavens never ordered Carpenter Stone to exert his skill and thereby break the body of Mount Tai nor did they instruct Ben and Yu to exercise all their power in order to harm the natural tendencies of the myriad people (使匠石以千歲之壽操鉤，視規矩，舉繩墨， 而正太山 ; 使賁、育帶干將而齊萬民 ; 雖畫力於巧，極盛於壽，太山不正，民不能齊。故曰：古之 牧天下者, 不使匠石極巧以敗太山之體, 不使賁、育盡威以傷萬民之性).” Han Feizi, chapter XXIX.

${ }^{41}$ Chong has argued that Xunzi, however, does not have an essentialist way of thinking about xing. See, Chong, "Xunzi and the Essentialist Mode of Thinking," 63.
} 
People are born with a fondness for profit ... raw hate ... desires of the senses and a fondness for lewd music and carnal pleasures. If they indulge in these, their natural tendencies will be chaotic and excessive and all appropriate ritual propriety and cultural rules will cease to exist. ${ }^{42}$

Xunzi observed a great danger in the indulgence of raw desire because it could lead to the destruction of society itself. Furthermore, if common people falling under the rule of raw desires could cause the destruction of the cultural and social foundation in a society, then it would be certainly more dangerous if such a person held a position of ruler. Those rulers who are dominated by unrestrained behavior serve as an example of the dangerous consequences of letting uncultivated natural tendencies dominate while in their original state without any kind of guidance or limitation. Xunzi used examples from literature, experience and history-for instance, Jie, the last ruler of the Xia dynasty, the same one criticized by $\mathrm{Han} \mathrm{Fei}^{43}$ — to explain the conduct and consequences of being guided by negative inclinations,

The reason people despise Jie, Robber $\mathrm{Zhi}^{44}$ and petty people is that they give free rein to their natural tendencies, follow their inclinations and are content to be unrestraint, so that their conduct is marked by greed and contentiousness. ${ }^{45}$

Han Fei continued to develop the same line of thought as Xunzi, based on the concerns raised by his teacher over the role that negative inclinations could have when they take control of undeveloped natural tendencies, by arguing that political decisions cannot originate in such unstable traits. Han Fei used the example of a mother's love-perhaps because it exemplifies one of the most potent feelings known to humankind-as a counterargument against the use of undeveloped inclinations as the foundation for political decisions. ${ }^{46}$ Even as powerful as the love of a mother is, Han Fei argued, love alone is not able to educate or guide children because regardless of how strong the love of their mother is, they still need teachers,

42“生而有好利焉 . . . 生而有疾惡焉 . . . 生而有耳目之欲, 有好聲色焉, 順是, 故淫亂生 而禮義文理亡焉.” Xunzi, chapter XXIII. All references to the Xunzi are from Xinyi Xunzi du ben 新譯荀 子讀本, ed. Wang Zhonglin 王忠林 (Taibei: Sanmin Shuju, 1997). Translations are based on Knoblock, Xunzi: A Translation and Watson, Xunzi: Basic Writings.

${ }^{43}$ See note 38 .

${ }^{44}$ For the story of Robber Zhi, see The Complete Works of Chuang Tzu [Zhuangzi], trans. Burton Watson (New York: Columbia University Press, 1968), chaps. 8, 10, and 29.

45“所賤於桀跖小人者, 從其性, 順其情, 安恣斈, 以出乎貪利爭奪. Xunzi, chapter XXIII.

${ }^{46} \mathrm{~A}$ caring mother, in loving her children, is exceeded by none. Yet, when the children engage in unruly actions, she sends them to follow a teacher; when they are seriously ill, she sends them to see a doctor. For without the guidance of a teacher they could fall victim to punishment; without the guidance of a doctor they could die. Even though the caring mother loves her children, she cannot save them from punishment and from death, then, what guides the children is not love. The natural tendency between the mother and the children is one of love, the authority of the ruler over the minister is one of planning. If the mother cannot use love to guide the family, how can the ruler maintain peace in the state through love? (慈母 之於弱 子也, 愛不可為前。然而弱子有僻行, 使之隨師; 有惡病, 使之事 醫。不随師則陷於刑, 不事醫則疑於死。慈母雖愛, 無益於振刑救 死。則存子者非愛也, 子母之性, 愛也。臣主之權, 箂也。母不能 以愛存家, 君安能 以愛持國 ? ). Han Feizi, chapter XLVII. 
doctors and society in general to educate and guide them. Han Fei contended that the Confucian literati of his time were mistakenly proposing that an accomplished person (ren 仁) should be a lenient and caring ruler in the same way mothers are towards their children. ${ }^{47}$

However, although leniency and compassion could be considered in themselves positive personal traits, in the political arena they could prove to have disastrous consequences. Han Fei was concerned that leniency tends be arbitrary and hence people, even those without merit, would expect personal favors from their superiors. But if being lenient is problematic, being stubborn could also pose problems, because that trait could make somebody too strict toward others and inflict punishment on everybody, including those who do not deserve it. Instead Han Fei proposed the laws as an alternative to the recommendations advanced by the literati of his time. This meant that the proper development of external guidelines—not personal inclinations - needed to become the guiding principle of a state.

On another passage, Han Fei based his analysis on the examples of history. He concluded that the ancient rulers achieved prosperity because they did not allow their raw desires or their private interest to govern. Instead they guarded the natural tendencies of people, respected and acknowledged the patterns ( $l i$ 理) of the heavens (tian天) and followed the laws. Thus there was a sense of personal responsibility on the part of the rulers, rather than a tendency to blame the people for mistakes that the rulers themselves had committed. Han Fei wrote,

The ancients never burdened their heart/mind with desires nor did they burden themselves with private interest, but they followed law and techniques in order to govern effectively and suppress chaos, relied on reward and punishment to praise what is preferred and punish what is not preferred and assigned all measures of lightness and heaviness to weight and scales. They never went against the patterns of the heavens, nor damage people's inclinations in their natural tendencies ... they were never severe beyond the boundary of the law nor lenient within the boundary of law, but observed acknowledged patterns in accordance with self-spontaneity. Thus, disaster and happiness originated on the dao

\footnotetext{
${ }^{47}$ “What preserves the state are not accomplished persons and appropriateness. Accomplished persons are caring and gentle and take wealth lightly; they are also cruel, have a harsh heart/mind and punish people easily. If one is caring and gentle, one will be unable to bear certain things; if one takes wealth lightly, one will be fond of giving favors. If one has a harsh heart/mind, one will reveal a hateful heart/mind to subordinates; if one punishes people easily, one will inflict rash executions to the people. Unable to bear certain things, then most punishments will be forgiven; fond of giving favors, one would mostly reward those without merit. When one reveals a hateful heart/mind, the inferiors will resent the superiors; when rash executions are instituted, the people will rebel. Therefore, if an accomplished person is on the throne, the inferiors will be unrestrained and will not care of the laws. They will expect undue gifts, and hope for favors from the superior. When a cruel individual is on the throne, laws and decrees are rashly applied; ruler and minister oppose each other; the people will be resentful and their heart/minds will give rise to chaos. Hence it is said: “both accomplished persons and cruelty will ruin the state (故存國者，非仁義也。仁者， 慈惠而輕財者也; 暴者, 心毅而易誅者也。慈惠則不忍, 輕財則好 與。心毅則憎心見於下, 易誅則妄殺加於人。不忍則罰多宥赦, 好 與則賞多無功。憎心見則下怨其上, 妄誅則民將背叛。故仁人在位 下肆而輕犯禁法, 偷幸而望於上; 暴人在位, 則法令妄而臣主 乘, 民怨而亂心生。故曰：仁暴者，皆亡國者也.)” Han Feizi, chapter XLVII.
} 
and the laws and did not originate on the love or undeveloped humanity of a person; the responsibility for glory or shame rested on oneself and not on the people. ${ }^{48}$

Like Xunzi before him, Han Fei warned that if the raw state of the natural tendencies in a person are not guided and given limits and such a person is provided with power and political position ( $\mathrm{shi}$ 勢), then the result could be catastrophic. ${ }^{49}$ History and experience showed him that because, there are more of those who are not able to take control over their desires, there are very few who are capable of governing well and bringing prosperity. Hence those in power need to be acknowledged as the main cause of chaos and, therefore, bear greater responsibility than anyone else in a state,

As for the inclinations of the natural tendencies, worthies are few and worthless persons many. Because the unworthy people who disturb the world are supplied with the advantage of power and political position, those who by means of their political position disturb the world are many and those who by means of their political position govern the world effectively are few. Indeed, political position is both an advantage to effective government and a facility to chaos. Hence the History of Zhou says: "do not add wings to tigers. Otherwise, they will fly into the village, catch people, and devour them." 50

According to Han Fei, experience and history have taught us that natural human tendencies are not perpetually "good" or "bad," but that humans have both negative and positive inclinations. Han Fei's significant contribution to the debate over xing was to move away from fixed positions and providing xing with empirical content by observing how it varies in changing historical and social circumstances. In other words, without taking into account the context in which humans are situated and defined, he was afraid that the debate was exhausting itself in empty exchanges without ever being able to offer a complete and satisfactory account of the complexity of human nature.

\footnotetext{
48“[古] 不以欲累心，不以私累己; 寄治亂於法術，託是非於賞罰， 屬輕重於權衡; 不逆天理, 不傷情性不急法之外, 不緩法之內; 守 成理, 因自然; 禍福生乎道法而不出乎愛惡, 榮辱之責在乎己, 而 不在 乎人."Han Feizi, chapter XXIX.

${ }^{49}$ It is worth noticing that Plato was also concerned with the negative influence that raw desires play in a tyrant. "A person becomes a tyrant," Plato explained, "when his nature and his practices or both together lead

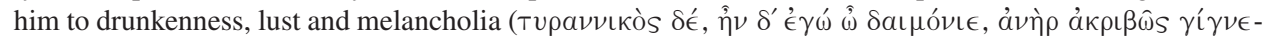

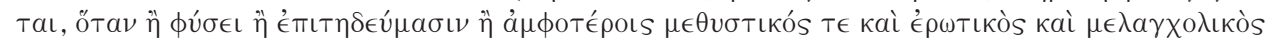

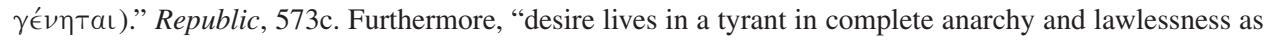
his sole ruler, and drives him as if he was a city, to dare anything that will provide sustenance for itself and

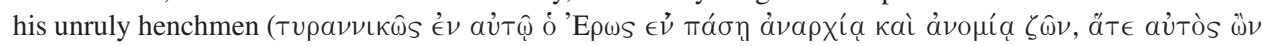

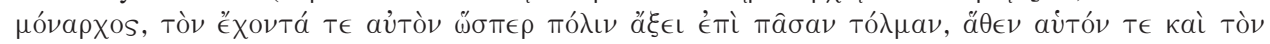

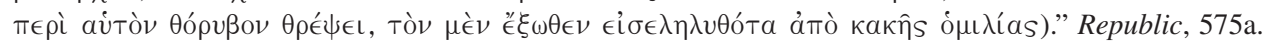
Translations are from Plato, Republic, trans. C. D. C. Reeve (Indianapolis: Hackett, 2004), but they have been modified when considered necessary. The Greek text is from Plato, Platonis Opera, ed. John Burnet (Oxford: Oxford University Press, 1903).

506人之情性, 賢者塞而不肖者眾, 而以威勢之利濟亂世之不肖人 則是以勢亂天下者多矣，以勢治天下者葟矣。夫勢者，便治而利 亂者也, 故周書日：曲為虎傅翼，將飛入邑，擇人而食之? ” Han Feizi, chapter XL. The quote at the end of the passage is probably from the Yizhoushu (逸周書).
} 
Furthermore, Han Fei thought, probably following his teacher, that the notion of the natural tendencies of people was a fundamental idea that allowed a deeper understanding of the basic ground of politics. This, one might say, is a function of xing that Han Fei inherited from Xunzi. As Karyn Lai explains, like his Confucian counterparts, for Han Fei, the natural tendencies of humans "are deeply intertwined with their respective views of the nature and aims of government and ultimately, of human life." 51 Therefore, this key notion provides a better sense of how Han Fei conceived the nature of the material upon which political societies are built.

Ultimately, what was considered fundamental to obtaining political order for Han Fei was the recognition that natural tendencies, in spite of possessing certain valuable inclinations, they also have others that are crude and undeveloped. This led Han Fei to conclude that the nature of humanity is unstable and changes according to circumstances: "it is in people's natural tendencies to live according to the circumstances." Humanity, therefore, in its most crude state must be acknowledged as fragile and in need of regulations and guidelines in order to channel its malleability. "In general," Han Fei wrote, "to govern effectively all under the heavens one must accord with the inclinations of the people. There are positive and undeveloped inclinations, therefore reward and punishment can be applied. If reward and punishment are applicable, standards and prohibitions will be achieved and the dao of effective government will be accomplished." ${ }^{53}$ Hence, those searching to establish enduring order needed to understand that xing was not a fixed essence, but that human tendencies could be channeled trough proper rewards and punishments. This is why the laws ( $f a$ 法) could appropriately regulate the actual changing characteristics of humanity.

But taking into consideration that the ontological ground of politics consists of historical circumstances did not turn Han Fei into a "relativist," as suggested by Geng Wu, Hsiao-po Wang and Leo S. Chang ${ }^{54}$ or an "existentialist," as suggested by Karyn L. Lai. ${ }^{55}$ On the contrary, as Wang and Chang clarified, Han Fei helps us to be aware that, "human nature is at least somewhat malleable" 56 and that "[he] was fully aware of the power of environmental circumstances for affecting human behavior, a view probably obtained from his teacher Xunzi."${ }^{57}$

${ }^{51}$ Lai, An Introduction to Chinese Philosophy, p. 187.

52“民 之 性，有生 之 實.” Han Feizi, chapter XLVIII.

53“凡治天下，必因人情。人情者有好惡，故賞罰可用；賞罰可用，則禁令可立，而治道具矣。” Han Feizi, chapter XLVIII. In this passage Han Fei seems to use the term qing (情) as the "capacity" that human beings have either for refinement or coarseness. This might be another notion inspired by Xunzi. See, Chong, "Xunzi and the Essentialist Mode of Thinking," 71.

${ }^{54}$ See, Wang Hsiao-po 王小波 and Leo S. Chang 張純, The Philosophical Foundations of Han Fei's Political Philosophy (Honolulu: University of Hawai'i Press, 1986), p. 51; Geng Wu, p. 43. See also, Wang Hsiao-po, "The Significance of the Concept of 'Fa' in Han Fei's Thought System," Philosophy East and West 27 (1977): 35-52.

${ }^{55}$ Lai, An Introduction to Chinese Philosophy, p. 186.

${ }^{56}$ Wang and Chang, The Philosophical Foundations of Han Fei's Political Philosophy, p. 51.

${ }^{57}$ Ibid. 